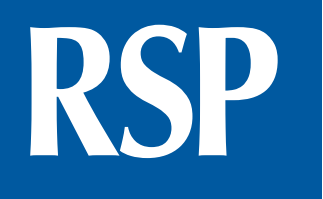

http://www.rsp.fsp.usp.br/
Revista de Saúde Pública

\title{
Diabetes mellitus mortality in a municipality in the state of São Paulo, 2010 to 2014
}

\author{
Rafael Aparecido Dias Lima' (iD, Plinio Tadeu Istilli" (iD, Carla Regina de Souza Teixeira" \\ Maria Lúcia Zanetti" (iD, Maria Tereza da Costa Gonçalves Torquato"II (iD) \\ ' Universidade de São Paulo. Escola de Enfermagem de Ribeirão Preto. Programa de Graduação em \\ Enfermagem. Ribeirão Preto, SP, Brasil \\ " Universidade de São Paulo. Escola de Enfermagem de Ribeirão Preto. Programa de Pós-Graduação em \\ Enfermagem Fundamental. Ribeirão Preto, SP, Brasil \\ I"' Prefeitura de Ribeirão Preto. Secretaria Municipal da Saúde de Ribeirão Preto. Programa de Atenção às Pessoas \\ com Doenças Crônicas não Transmissíveis. Ribeirão Preto, SP, Brasil
}

\section{ABSTRACT}

OBJECTIVE: To describe diabetes mellitus mortality according to sex and age in a municipality in the state of São Paulo, in the period ranging from 2010 to 2014.

METHODS: This was a temporal series ecological study carried out in Ribeirão Preto, state of São Paulo. The data was comprised of information on 583 deaths of Ribeirão Preto residents regardless of the place of death - from 2010 to 2014. The data source was the electronic system of the Epidemiological Surveillance of the Municipal Health Department of the evaluated municipality. Sex, age group, premature death and year of death were chosen as variables. Subsequently, age-standardized mortality rates were calculated using the World Health Organization's standard population, in addition to total and average per death potential years of life lost.

RESULTS: Mortality due to diabetes mellitus in the municipality increased during the studied period. There was a higher occurrence of female deaths, especially in the $\geq 80$ years age group. The highest rates of age-standardized mortality were male. For both sexes, there was an annual

Correspondence:

Carla Regina de Souza Teixeira Avenida Bandeirantes, 3900 Ribeirão Preto, SP, Brasil

E-mail: carlarst@eerp.usp.br

Received: Nov 6, 2017

Approved: Mar 9, 2018

How to cite: Lima RAD, Istilli PT, Teixeira CRS, Zanetti ML, Torquato MTCG. Diabetes mellitus mortality in a municipality in the state of São Paulo, 2010 to 2014. Rev Saude

Publica. 2019;53:24.

Copyright: This is an open-access article distributed under the terms of the Creative Commons Attribution License, which permits unrestricted use, distribution, and reproduction in any medium, provided that the original author and source are credited. mean increase of $9 \%$ in premature mortality during the studied period. Diabetes decreased life expectancy by 10 years.

CONCLUSIONS: As a diagnosis of local health care, the significant increase in agestandardized mortality rates, premature mortality and potential years of life lost in the studied municipality point to the need for improvements in health promotion and disease prevention measures. It is our hope that the results presented in this study contribute to the monitoring of mortality rates in the coming years.

DESCRIPTORS: Diabetes Mellitus, mortality. Risk Factors. Time Series Studies. 


\section{INTRODUCTION}

Due to being associated with high mortality rates, cardiovascular diseases, neoplasms, chronic respiratory diseases and diabetes mellitus (DM) are considered the main chronic noncommunicable diseases (CNCDs). The World Health Organization (WHO) has estimated a total of 38 million deaths from CNCDs in 2012, corresponding to $70 \%$ of all worldwide deaths ${ }^{1}$.

Among the four major CNCDs in 2012, cardiovascular diseases caused 17.5 million deaths, followed by neoplasms ( 8.2 million), chronic respiratory diseases (4 million) and DM (1.5 million). Furthermore, 16 million (42\%) CNCD deaths were premature and preventable ${ }^{1}$.

DM in particular has been increasing worldwide. The number of people with DM increased from 108 million in 1980 to 422 million in $2014^{2}$. In 2015, about five million people aged 20-79 died from DM, more than the sum of infectious-disease deaths in $2013^{3}$ (1.5 million deaths from HIV/AIDS, 1.5 million deaths from tuberculosis, and 0.6 million deaths from malaria). A study showed that, from 1980 to 2012, 955,455 people aged 20 years or more died from DM in Brazil. The same study also showed that when considering DM as the underlying or associated cause of mortality, the number of deaths increased to 1,076,434, reiterating how monitoring the DM population is important for the health system ${ }^{4}$.

Among the policy strategies to reduce the burden of DM mortality are the Global Action Plan for the Prevention and Control of NCDs, by the World Health Organization (WHO) and the Strategic Action Plan to Tackle Noncommunicable Diseases in Brazil, 2011-2022, by Brazil's Ministry of Health. The latter has three pillars: surveillance, health promotion, and comprehensive care ${ }^{6}$.

In the surveillance pillar, a mortality indicator aggregates and organizes information on population gaps related to morbidity, mortality and their risk factors. Information, evaluation and monitoring aim to define the population's vulnerability, and subsequently contribute to the qualification of health interventions, as well as the reduction of mortality rates ${ }^{7}$. Monitoring should be performed at all system management levels, from the municipal to the national ${ }^{8}$.

In view of the above, this study aims to describe DM mortality, according to sex and age, in a municipality in the state of São Paulo, from 2010 to 2014. It is our hope that this study is able to provide subsidies for DM monitoring, a fundamental activity of the Health Surveillance System, and contribute to the development of effective strategies in diabetes education.

\section{METHODS}

This was an ecological and time-trend study ${ }^{9}$, carried out in the city of Ribeirão Preto, located in the northeastern region of the state of São Paulo, 313 kilometers from its capital. The municipality has a total area of $650 \mathrm{~km}^{2}$ and a population of 604,682 inhabitants, according to the 2010 census $^{10}$.

The study population was comprised of deaths of residents of the municipality, regardless of the place of death, taking place from 2010 to 2014. These data were obtained from the Epidemiological Surveillance Division of the Municipal Health Department of Ribeirão Preto, state of São Pauilo, in 2017, after approval by the Ethics Committee of the School of Nursing of the University of São Paulo at Ribeirão Preto (EERP-USP), Process 2,111,771. Among 718 DM deaths, 135 were excluded, as the individuals were not residents of the studied municipality.

The data were segregated by the following variables: sex (female and male), age (in years) classified by age group $(0-4 ; 5-9 ; 10-14 ; 15-19 ; 20-24 ; 25-29 ; 30-34 ; 35-39 ; 40-44 ; 45-49$; $50-54 ; 55-59 ; 60-64 ; 65-69 ; 70-74 ; 75-79 ; \geq 80$ years), date of death, and cause of death. Age ranges were classified according to the Tab for Windows program (TABWIN), a free piece of software developed by Datasus ${ }^{11}$. The basic cause of death per the death certificate, and DM 
cases classified as E10 to E14 (according to the WHO's ICD-10 - International Classification of Diseases and Related Health Problems, 10th revision), were included in this study. E10 refers to insulin-dependent DM; E11, to non-insulin-dependent DM; E12, to malnutritionrelated DM; E13, to other specified types of DM; and E14, to unspecified $\mathrm{DM}^{1-12}$.

The obtained data were imported into Excel spreadsheets, for descriptive treatment and subsequent statistical analysis. In the first stage of analysis, deaths of Ribeirão Preto, residents were selected for inclusion, based on the deceased's documented city code. Statistical descriptive data analysis was performed using the Statistical Program For Social Sciences (SPSS), version 22 , for Windows. Descriptive data was presented using frequency and percentage of DM deaths spanning the 2010 to 2014 period, according to year, sex and age group.

DM age-standardized mortality rates (ASMR) per 100,000 inhabitants were calculated according to gender, age group and year of death, using WHO's standard population and the direct standardization method ${ }^{13,14}$. For individuals with 80 years of age or above, the number of deaths and the percentages established by the WHO were added together.

For premature mortality (people with $\geq 30$ and $\leq 69$ years of age), the methodology proposed by the WHO was employed 6 . Potential years of life lost (PYLL) were estimated using the method proposed by Romeder and McWhinnie ${ }^{15}$.

In order to gauge the period's rate reduction percentages, the annual rate reduction was initially calculated by dividing the difference between consecutive year rates by the rate in the initial year of the calculation (multiplied by 100). The resulting mean was defined as the period's annual reduction ${ }^{14}$.

\section{RESULTS}

In 2010-2014, a total of 583 deaths were attributed to DM in Ribeirão Preto, state of São Paulo. The DM type was unspecified for 494 (84.7\%) deaths. Acute complications (final character of the ICD-10 code: .0 or .1) were attributed to 10 (1.7\%) deaths. As for complication types, 161 (34.5\%) deaths were due to renal complications, $68(11.7 \%)$ due to peripheral circulatory complications, $52(8.9 \%)$ due to multiple complications, and $24(4.1 \%)$ due to other complications. It should be noted that 228 (39.1\%) deaths had no record of complications (Table 1).

Most deaths - $321(55.1 \%)$ - were female. The predominant age group was older people over 80 years of age $(n=194,33.3 \%)$. There was an expressive increase in the total number of deaths from 55 years of age onward (Table 2).

Table 1. Absolute number ( $\mathrm{n}$ ) and percentage (\%) distribution of deaths by diabetes mellitus, according to ICD-10 classification, Ribeirão Preto, 2010-2014. Ribeirão Preto, state of São Paulo, Brazil, 2017.

\begin{tabular}{|c|c|c|c|c|c|c|c|}
\hline \multirow{3}{*}{ ICD-10 final character } & \multicolumn{5}{|c|}{ ICD-10 code } & \multirow{2}{*}{\multicolumn{2}{|c|}{ Total }} \\
\hline & E10 & E11 ${ }^{b}$ & E12 & E13 $^{\mathrm{d}}$ & E14 ${ }^{\mathrm{e}}$ & & \\
\hline & \multicolumn{5}{|c|}{ Number of deaths } & $\mathbf{n}$ & $\%$ \\
\hline Comatose & 0 & 3 & 0 & 0 & 1 & 4 & 0.7 \\
\hline .1 Ketoacidosis & 0 & 0 & 0 & 0 & 6 & 6 & 1.0 \\
\hline .2 Renal complications & 6 & 34 & 0 & 0 & 161 & 201 & 34.5 \\
\hline .5 Peripheral circulatory complications & 0 & 7 & 0 & 0 & 61 & 68 & 11.7 \\
\hline .6 Other specified complications & 0 & 0 & 1 & 0 & 0 & 1 & 0.2 \\
\hline .7 Multiple complications & 1 & 6 & 1 & 0 & 44 & 52 & 8.9 \\
\hline .8 Unspecified complications & 0 & 1 & 0 & 0 & 22 & 23 & 3.9 \\
\hline .9 No complications & 5 & 24 & 0 & 0 & 199 & 228 & 39.1 \\
\hline $\mathrm{N}$ total & 12 & 75 & 2 & 0 & 494 & 583 & 100 \\
\hline$\%$ & 2.1 & 12.9 & 0.3 & 0 & 84.7 & 100 & \\
\hline
\end{tabular}

Source: Epidemiological Surveillance Division of the Municipal Secretariat of Ribeirão Preto.

a E10 - insulin-dependent diabetes mellitus.

${ }^{b}$ E11 - non-insulin-dependent diabetes mellitus.

${ }^{\mathrm{C}}$ E12 - malnutrition-related diabetes mellitus.

${ }^{d}$ E13 - other specified types of diabetes mellitus.

e E14 - unspecified diabetes mellitus. 
Regarding sex, women had a mean of 64.2 deaths/year, and men had a mean of 52.4 deaths/ year. Regarding ASMR, there was a 38.5\% increase from the first to the last year of the study, in both sexes (Table 3).

Among 583 deaths, 229 (39.3\%) were considered premature. Among premature deaths, 129 (22.1\%) were male. The average PYLL was 10.4 years (Table 4).

Table 2. Absolute number (n), percentage (\%) and age-standardized mortality rate (ASMR) distribution for diabetes mellitus deaths of Ribeirão Preto residents, 2010 to 2014, according to sex and age group. Ribeirão Preto, state of São Paulo, Brazil, 2017.

\begin{tabular}{|c|c|c|c|c|c|c|c|c|c|}
\hline \multirow[b]{2}{*}{ Age group } & \multicolumn{3}{|c|}{ Male sex } & \multicolumn{3}{|c|}{ Female sex } & \multicolumn{3}{|c|}{ Total } \\
\hline & n & $\%$ & $\begin{array}{c}\text { ASMR } \\
\text { (per 100,000 } \\
\text { inhabitants) } \\
\end{array}$ & $\mathbf{n}$ & $\%$ & $\begin{array}{c}\text { ASMR } \\
\text { (per 100,000 } \\
\text { inhabitants) } \\
\end{array}$ & $\mathbf{n}$ & $\%$ & $\begin{array}{c}\text { ASMR } \\
\text { (per 100,000 } \\
\text { inhabitants) }\end{array}$ \\
\hline $0-4$ & 0 & 0 & 0.0 & 0 & 0 & 0.0 & 0 & 0 & 0.0 \\
\hline $5-9$ & 1 & 0.2 & 0,4 & 0 & 0 & 0.0 & 1 & 0.2 & 0.2 \\
\hline $10-14$ & 0 & 0 & 0.0 & 0 & 0 & 0.0 & 0 & 0 & 0.0 \\
\hline $15-19$ & 0 & 0 & 0.0 & 1 & 0.2 & 0.4 & 1 & 0.2 & 0.2 \\
\hline $20-24$ & 1 & 0.2 & 0.3 & 1 & 0.2 & 0.3 & 2 & 0.3 & 0.3 \\
\hline $25-29$ & 1 & 0.2 & 0.3 & 1 & 0.2 & 0.3 & 2 & 0.3 & 0.3 \\
\hline $30-34$ & 2 & 0.3 & 0.6 & 0 & 0 & 0.0 & 2 & 0.3 & 0.3 \\
\hline $35-39$ & 5 & 0.9 & 1.6 & 1 & 0.2 & 0.3 & 6 & 1.0 & 1.0 \\
\hline $40-44$ & 4 & 0.7 & 1.3 & 8 & 1.4 & 2.4 & 12 & 2.1 & 1.9 \\
\hline $45-49$ & 4 & 0.7 & 1.3 & 1 & 0.2 & 0.3 & 5 & 0.9 & 0.7 \\
\hline $50-54$ & 10 & 1.7 & 3.2 & 9 & 1.5 & 2.4 & 19 & 3.3 & 2.8 \\
\hline $55-59$ & 30 & 5.2 & 9.8 & 14 & 2.4 & 3.8 & 44 & 7.6 & 6.6 \\
\hline $60-64$ & 31 & 5.3 & 10.9 & 35 & 6.0 & 9.8 & 66 & 11.3 & 10.3 \\
\hline $65-69$ & 43 & 7.4 & 16.9 & 32 & 5.5 & 9.6 & 75 & 12.9 & 12.8 \\
\hline $70-74$ & 34 & 5.8 & 13.3 & 31 & 5.3 & 8.5 & 65 & 11.2 & 10.5 \\
\hline $75-79$ & 34 & 5.8 & 13.3 & 55 & 9.4 & 13.9 & 89 & 15.3 & 13.7 \\
\hline $80+$ & 62 & 10.6 & 24.8 & 132 & 22.7 & 26.9 & 194 & 33.3 & 26.2 \\
\hline Total & 262 & 44.9 & 90.3 & 321 & 55.1 & 102.1 & 583 & 100 & 96.4 \\
\hline
\end{tabular}

Source: Epidemiological Surveillance Division of the Municipal Secretariat of Ribeirão Preto.

Table 3. Absolute number (n), percentage (\%), and age-standardized mortality rate (ASMR) distribution for diabetes mellitus deaths of Ribeirão Preto residents, 2010 to 2014, according to sex and year. Ribeirão Preto, state of São Paulo, Brazil, 2017.

\begin{tabular}{|c|c|c|c|c|c|c|c|c|c|}
\hline \multirow[b]{2}{*}{ Year } & \multicolumn{3}{|c|}{ Male sex } & \multicolumn{3}{|c|}{ Female sex } & \multicolumn{3}{|c|}{ Total } \\
\hline & $\mathbf{n}$ & $\%$ & $\begin{array}{c}\text { ASMR } \\
\text { (per 100,000 } \\
\text { inhabitants) }\end{array}$ & $\mathbf{n}$ & $\%$ & $\begin{array}{c}\text { ASMR } \\
\text { (per 100,000 } \\
\text { inhabitants) }\end{array}$ & $\mathbf{n}$ & $\%$ & $\begin{array}{c}\text { ASMR } \\
\text { (per 100,000 } \\
\text { inhabitants) }\end{array}$ \\
\hline 2010 & 47 & 8.1 & 17.5 & 57 & 9.8 & 14.1 & 104 & 17.8 & 15.6 \\
\hline 2011 & 51 & 8.7 & 19.2 & 46 & 7.9 & 11.5 & 97 & 16.6 & 14.7 \\
\hline 2012 & 54 & 9.3 & 20.3 & 69 & 11,8 & 17.0 & 123 & 21.1 & 18.5 \\
\hline 2013 & 51 & 8.7 & 19.1 & 63 & 10.8 & 15.4 & 114 & 19.6 & 17.2 \\
\hline 2014 & 59 & 10.2 & 21.8 & 86 & 14.7 & 20.9 & 145 & 24.9 & 21.6 \\
\hline
\end{tabular}

Source: Epidemiological Surveillance Division of the Municipal Secretariat of Ribeirão Preto.

Table 4. Absolute number (n), percentage (\%), age-standardized mortality rate (ASMR), and potential years of life lost (PYLL) distribution for premature deaths (30-69 years) of Ribeirão Preto residents due to diabetes mellitus, 2010 to 2014, according to sex and year. Ribeirão Preto, state of São Paulo, Brazil, 2017.

\begin{tabular}{|c|c|c|c|c|c|c|c|c|c|c|c|c|c|c|c|c|c|c|}
\hline \multirow[b]{3}{*}{ Year } & \multicolumn{6}{|c|}{ Male sex } & \multicolumn{6}{|c|}{ Female sex } & \multicolumn{6}{|c|}{ Total } \\
\hline & \multicolumn{3}{|c|}{ Premature death } & \multicolumn{3}{|c|}{ PYLL } & \multicolumn{3}{|c|}{ Premature death } & \multicolumn{3}{|c|}{ PYLL } & \multicolumn{3}{|c|}{ Premature death } & \multicolumn{3}{|c|}{ PYLL } \\
\hline & $\mathbf{n}$ & $\%$ & $\begin{array}{c}\text { ASMR (per } \\
100,000 \\
\text { inhabitants) }\end{array}$ & $\mathbf{n}$ & $\%$ & $\begin{array}{c}\text { Per } \\
\text { death }\end{array}$ & $\mathbf{n}$ & $\%$ & $\begin{array}{c}\text { ASMR (per } \\
100,000 \\
\text { inhabitants) }\end{array}$ & $\mathbf{n}$ & $\%$ & $\begin{array}{c}\text { Per } \\
\text { death }\end{array}$ & $\mathbf{n}$ & $\%$ & $\begin{array}{c}\text { ASMR (per } \\
100,000 \\
\text { inhabitants) }\end{array}$ & $\mathbf{n}$ & $\%$ & $\begin{array}{c}\text { Per } \\
\text { death }\end{array}$ \\
\hline 2010 & 24 & 4.1 & 8.5 & 243 & 10.2 & 10.1 & 16 & 2.7 & 4.6 & 207 & 8.7 & 12.9 & 40 & 6.9 & 6.3 & 450 & 18.8 & 11.3 \\
\hline 2011 & 25 & 4.3 & 8.9 & 270 & 11.3 & 10.8 & 15 & 2.6 & 4.2 & 142 & 5.9 & 9.5 & 40 & 6.9 & 6.3 & 412 & 17.3 & 10.3 \\
\hline 2012 & 23 & 3.9 & 8.2 & 271 & 11.4 & 11.8 & 22 & 3.8 & 6.2 & 227 & 9.5 & 10.3 & 45 & 7.7 & 7.1 & 498 & 20.9 & 11.1 \\
\hline 2013 & 26 & 4.5 & 9.2 & 260 & 10.9 & 10 & 17 & 2.9 & 4.9 & 133 & 5.6 & 7.8 & 43 & 7.4 & 6.9 & 393 & 16.5 & 9.1 \\
\hline 2014 & 31 & 5.3 & 10.7 & 349 & 14.6 & 11.3 & 30 & 5.2 & 8.7 & 285 & 11.9 & 9.5 & 61 & 10.5 & 9.6 & 634 & 26.6 & 10.4 \\
\hline Total & 129 & 22.1 & 45.5 & 1,393 & 58.4 & 10.8 & 100 & 17.2 & 28.6 & 994 & 41.6 & 9.9 & 229 & 39.3 & 36.2 & 2,387 & 100 & 10.4 \\
\hline
\end{tabular}

Source: Division of Epidemiological Surveillance of the Municipal Secretariat of Ribeirão Preto. 


\section{DISCUSSION}

The municipality saw a total of $583 \mathrm{DM}$ deaths during the studied period, and an increase in ASMR from 15.6 per 100,000 inhabitants in 2010 to 21.6 in 2014. The Global Burden of Disease study carried out in 195 countries showed that there was an increase in DM mortality in Brazil from 1990 to 2015, as well as an increase in ASMR - from 35.9 per 100,000 inhabitants in 1990 to 37.5 in $2015^{16}$. Despite the mortality rate increase shown here, our results for Ribeirão Preto (21.6 per 100,000 inhabitants in 2014) are still below the national average. In contrast, a Canadian study showed an approximately one-quarter decline in age-standardized DM mortality between 1995 and $2005^{17}$.

This study found that the main specific causes of death due to DM were renal complications, responsible for $34.5 \%$ of deaths, peripheral circulatory complications, $11.7 \%$, and multiple complications, $8.9 \%$. For $39.1 \%$ of deaths, no complications were reported. A Brazilian study evaluating DM mortality between 1996 and 2011, including 294,203 deaths, showed that renal complications (19.1\%) and peripheral circulatory complications (6.1\%) were the main specific causes of death from DM. It is noteworthy that $7 \%$ of the deaths were due to unspecified complications. In the majority (51.9\%) ofDM deaths in the period, there were no complications ${ }^{18}$.

Acute complications, ketoacidosis and coma accounted for only $1.7 \%$ of deaths, which is consistent with the literature ${ }^{19}$, and confirms that the free supply of insulin and other necessities to people with DM was a milestone of the Brazilian health system ${ }^{19}$. When analyzing the obtained results, the higher DM mortality in the female sex (55.1\% of deaths) stood out. This percentage was similar to the one found by a Brazilian nationwide study (57.7\%) which described DM mortality from 1980 to $2012^{4}$.

From 2010 to 2014, there was a yearly average ASMR increase of 7\% (from 15.5 to 21.6 per 100,000 inhabitants), affecting both sexes. In the same period, the average increase for the male sex was $4 \%$ per year (from 17.5 to 21.8 per 100,000 inhabitants), while for the female sex it was $8 \%$ per year (from 14.1 to 20.9 per 100,000 inhabitants). The results found here are in agreement with another Brazilian, ecological and time-series study, which evaluated the pattern of DM mortality according to sex from 1980 to $2012^{4}$. However, despite the fact that in the aforementioned study ASMR also increased for both sexes, the increase rates were lower: $2.9 \%$ per year for men (20.8 per 100,000 inhabitants in 1980 to 47.6 in 2012) and 1.7\% per year for women (28.7 per 100,000 inhabitants in 1980 to 47.2 in 2012). The study also showed that towards the end of the 1980-2012 period this relationship was reversed, with female mortality higher in the initial years of the survey and male mortality higher in its final years ${ }^{4}$. The ASMR distribution according to sex found by this study showed higher values for men than for women, in all the evaluated years. However, between 2010 and 2014 the yearly increase in average female DM mortality was double that of men, which points to a possible reversal in the future, with higher DM ASMR in the female sex.

ASMR rates increased gradually with age, for both sexes, indicating a dependence on population aging. Among deaths in the female sex, 132 (22.7\%) were in the 80 years or more age group, more than double the number of male deaths in the same age group $(62,10.6 \%)$. According to estimates by the International Diabetes Federation (2015), women had a greater incidence and prevalence of DM at the apex of their aging when compared to males with the same age and, therefore, a higher mortality rate in the higher age groups ${ }^{3}$. This may be explained by the higher number of premature deaths attributed to external causes in males, a preeminent feature of developing countries, leading to greater survival rates in females, as observed in other studies ${ }^{3,16,20-23}$. A study evaluated 264 causes of death, including DM, in 195 countries from 1980 to 2016, and found that DM deaths in older people over 70 years of age increased by approximately $90 \%$ throughout the studied period ${ }^{24}$.

We found an average PYLL loss of 10 years for each premature death (at 30 to 69 years of age), that is, DM withdrew 10 years of economically active life from each person who died 
from the disease. Therefore, premature deaths together with PYLL strengthen the impact of DM on individuals, families, communities and the country, as it overburdens health services and causes early retirement, harming economic development ${ }^{3}$.

Our study also found an increase in premature mortality rates. The average increase was $5 \%$ per year for men (8.5 to 10.7 per 100,000 inhabitants), 14\% for women (4.6 to 8.7 per 100,000 inhabitants) and $9 \%$ for both sexes (6.3 to 9.6 per 100,000 inhabitants). However, a national study showed a decline in the rate of premature DM mortality in Brazil, which went from 40.6 per 100,000 inhabitants in 2000 to 33.7 in 2011 (a 1.7\% yearly reduction). The study projected a drop to 26.9 per 100,000 inhabitants by $2022^{14}$.

The goal of the national plan for tackling CNCDs is to reduce premature mortality rate to $2 \%$ a year ${ }^{7}$, which has not yet been achieved. Thus, although the municipality of Ribeirão Preto, had a marked ASMR increase in both premature and overall deaths - and mainly in the female sex - local death rates were still lower than the national averages. These discrepancies suggest that a general increase in the incidence and prevalence of DM is occurring. A plausible explanation for this situation is the disorganized industrial and urban growth of most Brazilian municipalities, coupled with the adoption of harmful life habits by the majority of the population, which increase the likelihood of developing chronic diseases such as $\mathrm{DM}^{25}$.

The deleterious long-term effects of hyperglycemia on people suffering from DM, associated with the increase in premature mortality, calls for reflection on public health policies, in order to propose effective interventions against DM. Thus, this study may contribute to advances in local health diagnosis, and serve as basis for new subsidies towards preventive and health promotion measures, with a consequent reduction in the rates of premature mortality and DM mortality ${ }^{26}$.

Another study described mortality rates in all Brazilian capitals, from 1980 to $2007^{27}$, and observed increases in ASMR mainly in North and Northeast capitals. The city of Porto Velho, state of Rondônia, had an ASMR of 9.76 per 100,000 inhabitants in the first four years, and this number increased to 46.13 in the last four years. In São Luís, state of Maranhão, ASMR increased from 24.75 in the first quadrennium to 54.38 in the last.

In the Southeastern region, two capitals had a decline in ASMR: Belo Horizonte, state of Minas Gerais, and São Paulo, state of São Paulo, with a drop from 28.82 per 100,000 inhabitants in the first four-year period to 18.36 in the last, and from 28.94 in the first fouryear period to 22.05 in the last, respectivel $y^{27}$. These data, however, differs from the results of our study, which, although performed in the same geographic region, showed an increase in ASMR during the evaluated period.

Accessibility to health services may be a determining factor of such macro-regional contrasts. In fact, a nationwide study ${ }^{28}$ on the population's access to primary care teams certified by the National Program for Access and Quality Improvement in Primary Care (PMAQ-AB) found a greater possibility of access in the Southeast, a lesser possibility in the North, and a greater concentration of family health teams in the capitals ${ }^{28}$. These data highlight the relevance of studies such as ours and the need for future research analyzing DM mortality rates and other CNCDs in medium or small municipalities.

One of this study's limitations was the underreporting of the disease in death certificates, which may have led to an underestimation of DM mortality rates. Also, there was no investigation and redistribution of possible insufficiently defined causes of death related to endocrine diseases, as performed in other studies ${ }^{14,18,29}$. Another limitation of this study is the impossibility of describing mortality according to specific DM types, since the majority of the deaths were classified as E14 $(84.7 \%)^{19}$. In order to reduce underreporting, it is necessary to reinforce the importance of adequate completion of the death certificate by the physician. Furthermore, epidemiological surveillance teams trained in monitoring all spheres have to be implemented, in order to investigate insufficiently defined causes ${ }^{30}$. 
In conclusion, the results show that DM mortality in the city of Ribeirão Preto, state of São Paulo, Brazil increased in the 2010 to 2014 period. There was a higher occurrence of deaths in females, but ASMRs were higher in males. As to age, there was a predominance of deaths in the 80 years or more age group. For both sexes, there was an annual mean increase of $9 \%$ in premature mortality during the studied period. DM deaths are responsible for the withdrawal of 10 years of life expectancy. These results may support public policies in the prevention of DM mortality, as well as health promotion towards adult individuals with DM.

\section{REFERENCES}

1. World Health Organization. Global status report on noncommunicable diseases 2014. Geneva: WHO; 2014 [cited 2017 Oct 31]. Available from: http://www.who.int/nmh/publications/ncdstatus-report-2014/en/

2. World Health Organization. Global report on diabetes. Geneva: WHO; 2016 [cited 2017 Oct 31]. Available from: http://apps.who.int/iris/bitstream/handle/10665/204871/9789241565257_ eng.pdf;jsessionid=814AB1D426D423740A961B225CFA8009? sequence $=1$

3. International Diabetes Federation. IDF Diabetes Atlas. 7. ed. Brussels: IDF; 2015.

4. Malhão TA, Brito AS, Pinheiro RS, Cabral CS, Camargo TMCR, Coeli CM. Sex differences in diabetes mellitus mortality trends in Brazil, 1980-2012. PLoS One. 2016;11(6):e0155996. https://doi.org/10.1371/journal.pone.0155996

5. World Health Organization. WHO Global action plan for the prevention and control of noncommunicable disease (NCDs) 2013-2020. Geneva: WHO; 2013 [cited 2017 Oct 31]. Available from: http://www.who.int/nmh/events/ncd_action_plan/en/

6. Ministério da Saúde (BR), Secretaria de Vigilância em Saúde, Departamento de Análise de Situação de Saúde. Plano de ações estratégicas para o enfrentamento das Doenças Crônicas Não Transmissíveis (DCNT) no Brasil 2011-2022. Brasília (DF); 2011 [cited 2017 Oct 31]. (Série B. Textos Básicos de Saúde). Available from: http://bvsms.saude.gov.br/publicacoes/plano_acoes_ enfrent_dcnt_2011.pdf

7. Malta DC, Merhy EE. O percurso da linha do cuidado sob a perspectiva das doenças crônicas não transmissíveis. Interface (Botucatu). 2010;14(34):593-606. https://doi.org/10.1590/S1414-32832010005000010

8. Malta DC, Cezário AC, Moura L, Morais Neto OL, Silva Jr JB. A construção da vigilância e prevenção das doenças crônicas não transmissíveis no contexto do Sistema Único de Saúde. Epidemiol Serv Saude. 2006;15(1):47-65. https://doi.org/10.5123/S1679-49742006000300006

9. Medronho RA, Bloch KV, Luiz RR, Werneck GL. Epidemiologia. 2.ed. São Paulo: Atheneu; 2009.

10. Instituto Brasileiro de Geografia e Estatística. Censo 2010. Rio de Janeiro: IBGE; 2010 [cited 2017 Oct 31]. Available from: https://censo2010.ibge.gov.br/

11. Ministério da Saúde (BR). Datasus: apresentação TabWin. Brasília (DF); 2010 [cited 2017 Oct 31]. Available from: http://datasus.saude.gov.br/apresentação

12. Duncan BB, Stevens A, Iser BPM, Malta DC, Azevedo e Silva G, Schmidt MI. Mortalidade por doenças crônicas no Brasil: situação em 2009 e tendências de 1991 a 2009. In: Ministério da Saúde (BR), Secretaria de Vigilância em Saúde, Departamento de Análise de Situação em Saúde. Saúde Brasil 2010: uma análise da situação de saúde e de evidências selecionadas de impacto de ações de vigilância em saúde. Brasília (DF; 2011 [cited 2017 Oct 31]. p.117-36. (Série G. Estatística e Informação em Saúde). Available from: http://portal.saude.gov.br/portal/arquivos/pdf/ cap_5_saude_brasil_2010.pdf

13. Ahmad OB, Boschi-Pinto C, Lopez AD, Murray CJL, Lozano R, Inoue M. Age standardization of rates: a new WHO standard. Geneva: World Health Organization; 2001 [cited 2017 Oct 31]. (GPE Discussion Paper Series, 31). Available from: http://www.who.int/healthinfo/paper31.pdf

14. Malta DC, Moura L, Prado RR, Cortez-Escalante J, Schmidt MI, Duncan BB. Mortalidade por doenças crônicas não transmissíveis no Brasil e suas regiões, 2000 a 2011. Epidemiol Serv Saude. 2014;23(4):599-608. https://doi.org/10.5123/S1679-9742014000400002

15. Romeder JM, McWhinnie JR. Potencial Years of Life Lost between ages 1 and 70: an indicator of premature mortality for health planning. Int J Epidemiol. 1977;6(2):143-51. https://doi.org/10.1093/ije/6.2.143 
16. Duncan BB, Schmidt MI, Ewerton C, Moradi-Lakeh M, Passos VMA, França EB, et al. The burden of diabetes and hyperglycemia in Brazil-past and present: findings from the Global Burden of Disease Study 2015. Diabetol Metab Syndr. 2017;9:18. https://doi.org/10.1186/s13098-017-0216-2

17. Lipscombe LL, Hux JE. Trends in diabetes prevalence incidence, and mortality in Ontario, Canada 1995-2005: a population-based study. Lancet. 2007;369(9563):750-6. https://doi.org/10.1016/S0140-6736(07)60361-4

18. Schmidt MI, Duncan BB, Ishitani L, Franco GC, Abreu DM, Lana GC, et al. Trends in mortality due to diabetes in Brazil, 1996-2011. Diabetol Metab Syndr. 2015;7:109. https://doi.org/10.1186/S13098-015-0105-5

19. Klafke A, Duncan BB, Rosa RS, Moura L, Malta DC, Schmidt MI. Mortalidade por complicações agudas do diabetes melito no Brasil, 2006-2010. Epidemiol Serv Saude. 2014;23(3):455-62. https://doi.org/10.2123/S1679-49742014000300008

20. Stevens A, Schmidt MI, Duncan BB. Gender inequalities in non-communicable disease mortality in Brazil. Cienc Saude Coletiva. 2012;17(10):2627-34. https://doi.org/10.1590/S1413-81232012001000012

21. Alegre-Díaz J, Herrington W, López-Cervantes M, Gnatiuc L, Ramirez R, Hill M, et al. Diabetes and cause-specific mortality in Mexico City. N Engl J Med. 2016;375(20):1961-71. https://doi.org/10.1056/NEHMoa1605368

22. Kautzky-Willer A, Harreiter J, Pacini G. Sex and gender differences in risk, pathophysiology and complications of type 2 diabetes mellitus. Endrocr Rev. 2016;37(3):278-316. https://doi.org/10.1210/er.2015-1137

23. Cheng YJ, Imperatore G, Geiss LS, Wang J, Saydah SH, Cowie CC, et al. Secular changes in the age-specific prevalence of diabetes among U.S. adults: 1988-2010. Diabetes Care. 2013;36(9):2690-6. https://doi.org/10.2337/dc12-2074

24. GMB 2016 Causes of Death Collaborators. Global, regional and national agesex specific mortality for 264 causes of death, 1980-2016: a systematic analysis for the Global Burden of Disease Study 2016. Lancet. 2017;390(10100):1151-210. https://doi.org/10.1016/S0140-6736(17)32152-9

25. Schmidt MI, Duncan BB, Azevedo e Silva G, Menezes AM, Monteiro CA, Barreto SM, et al. Chronic noncommunicable diseases in Brazil: burden and current challenges. Lancet. 2011;377(9781):1949-61. https://doi.org/10.101/S0140-736(11)60135-9

26. Bertoldi AD, Kanavos P, França GVA, Carraro A, Tejada CAO, Hallal PC, et al. Epidemiology, management, complications and costs associated with type 2 diabetes in Brazil: a comprehensive literature review. Global Health. 2013;9:62. https://doi.org/10.1186/1744-8603-9-62

27. Mattos PE, Luz LL, Santiago LM, Mattos IE. Tendência da mortalidade por diabetes melito em capitais brasileiras, 1980-2007. Arq Bras Endocrinol Metab. 2012;56(1):39-46. https://doi.org/10.1590/S0004-27302012000100007

28. Alves MGM, Casotti E, Oliveira LGD, Machado MTC, Almeida PF, Corvino MPF, et al. Fatores condicionantes para o acesso às equipes da Estratégia Saúde da Família no Brasil. Saude Debate. 2014;38 No Espec:34-51. https://doi.org/10.5935/0103-1104.2014S004

29. França E, Teixeira R, Ishitani L, Duncan BB, Cortez-Escalante JJ, Morais Neto OL, et al. Causas mal definidas de óbito no Brasil: método de redistribuição baseado na investigação do óbito. Rev Saude Publica. 2014;48(4):671-81. https://doi.org/10.1590/S0034-8910.2014048005146

30. França EB, Cunha CC, Vasconcelos AMN, Cortez-Escalante JJ, Abreu DX, Lima RB, et al. Avaliação da implantação do programa "Redução do percentual de óbitos por causas mal definidas" em um estado do Nordeste do Brasil. Rev Bras Epidemiol. 2014;17(1):119-34. https://doi.org/10.1590/1415-790X201400010010ENG

Funding: National Council for Scientific and Technological Development (CNPq - Process 164427 / 2015-5)

Authors' Contributions: Study design and planning: RADL, PTI, CRST, MLZ. Analysis and interpretation of the data, drafting of the manuscript: RADL, PTI, CRST. Manuscript critical review: CRST, MLZ, MTCGT. All authors have approved the final version of the manuscript and assume public responsibility for its contents.

Conflict of Interest: The authors declare no conflict of interest. 